\title{
LÚDICA POÉTICA
}

Tezcoco fue el centro donde con mayor vigor floreció el pensamiento de los sabios y poetas cultores de la doctrina de la flor y el canto, es decir, el valor supremo del arte. Entre los poetas indígenas figura el también gobernante Cuacuauhtzin (1443) "cantor de la amistad traicionada", nada menos que por parte del gran Nezahualcóyotl. Este al conocer a la joven princesa Azcalxochitzin, prometida de aquél, "muy hermosa y dotada de gracias y bienes de naturaleza", ordenó en secreto enviarlo al frente de batalla para que allí muriera. Al conocer el motivo de tal sentencia, cayó en profunda tristeza. Testimonio de su tragedia es este precioso poema.

\section{Canto triste de Cuacuauhtzin*}

Flores con ansia mi corazón desea.

Que estén en mis manos.

Con cantos me aflijo,

sólo ensayo cantos en la tierra.

Yo, Cuacuauhtzin,

con ansia deseo las flores,

que estén en mis manos,

yo soy desdichado.

¿A dónde en verdad iremos

que nunca tengamos que morir?

Aunque fuera yo piedra preciosa,

aunque fuera oro,

seré yo fundido,

allá en el crisol seré perforado.

Sólo tengo mi vida,

yo, Cuacuauhtzin, soy desdichado.

Tu atabal de jades,

tu caracol rojo y azul así los haces ya resonar,

tú, Yoyontzin.

Ya ha llegado,

ya se yergue el cantor.

Por poco tiempo alegraos,

vengan a presentarse aquí

los que tienen triste el corazón.

Ya ha llegado,

ya se yergue el cantor.

Deja abrir la corola a tu corazón, deja que ande por las alturas.

Tú me aborreces,

tú me destinas a la muerte.

Ya me voy a su casa, pereceré.

Acaso por mí tú tengas que llorar,

\footnotetext{
* Tomado de PORTILLA, León Miguel, Trece poetas de mundo azteca, UNAM, México, 3a r., 1984, p.85.
} 
por mi tengas que afligirte,

tú, amigo mío,

pero yo ya me voy,

yo ya me voy a su casa.

Sólo esto dice mi corazón,

no volveré una vez más,

jamás volveré a salir sobre la tierra,

yo ya me voy, ya me voy a su casa.

Sólo trabajo en vano, gozad, gozad, amigos nuestros.

¿No hemos de tener alegría,

no hemos de conocer el placer, amigos nuestros?

LLevaré conmigo las bellas flores, los bellos cantos.

Jamás lo hago en el tiempo del verdor,

sólo soy menesteroso aquí,

sólo yo, Cuacuauhtzin.

¿No habremos de gozar,

no habremos de conocer el placer, amigos nuestros?

LLevare conmigo las bellas flores, los bellos cantos.

\title{
Quiero igual que tú
}

\author{
Quiero, \\ igual que tú, \\ caminar por las calles abrazando \\ la luna y las estrellas. \\ Quiero \\ igual que tú, descubrir \\ donde se juntan \\ los sueños y la vida, \\ los pobres y los ricos \\ los niños y los viejos, \\ el tiempo y la distancia. \\ Quiero, \\ igual que tú, \\ comprender \\ por qué el celeste cielo \\ no muestra en sus fulgores \\ la sangre que del suelo \\ salpica cada día \\ el infinito. \\ Quiero, \\ igual que tú, \\ descubrir en cada hombre
}


una plácida mirada

y un canto de esperanza,

que me permita

definir entonces,

cúal es alfin

la esencia de vivir.

Nelly Martínez 
Febrero 19 de 1993

\section{Deconstrucción}

A los pueblos de América Latina

Sobre tus ruinas,

entre el hambre

la muerte

y la ira

desbocada

por la

acumulación

de la miseria

$y$ el desastre,

se levanta

tu rostro

triangular

y seguro

con la sonrisa

plena

para encender

las velas

que tanto

necesita

la humanidad

entera.

Amparo Molina 